\title{
Development and Validation of an RP-HPLC Method for Estimation of Chlorpheniramine Maleate, Ibuprofen, and Phenylephrine Hydrochloride in Combined Pharmaceutical Dosage Form
}

\author{
Pinak M. Sanchaniya, Falgun A. Mehta, and Nirav B. Uchadadiya \\ Indukaka Ipcowala College of Pharmacy, Beyond GIDC, P.B. No. 53, Vitthal Udyognagar, Gujarat 388121, India \\ Correspondence should be addressed to Pinak M. Sanchaniya; pinaksanchania@gmail.com
}

Received 25 March 2013; Revised 27 May 2013; Accepted 9 June 2013

Academic Editor: Susana Casal

Copyright (C) 2013 Pinak M. Sanchaniya et al. This is an open access article distributed under the Creative Commons Attribution License, which permits unrestricted use, distribution, and reproduction in any medium, provided the original work is properly cited.

\begin{abstract}
The objective of this paper is to develope a simple, precise, accurate, and reproducible reversed phase high performance liquid chromatographic method for the quantitative determination of chlorpheniramine maleate, ibuprofen, and phenylephrine hydrochloride in combined pharmaceutical dosage form. Analysis was carried out using acetonitrile: mathanol:phoshphate buffer $(50: 20: 30$, $\mathrm{v} / \mathrm{v} / \mathrm{v}, \mathrm{pH} 5.6)$ mobile phase at $1.0 \mathrm{~mL} / \mathrm{min}$ flow rate and Sunfire C 18 column $(5 \mu \mathrm{m} \times 250 \mathrm{~mm} \times 4.6 \mathrm{~mm})$ as stationary phase with detection wavelength of $220 \mathrm{~nm}$. The retention times of chlorpheniramine maleate (CPM), ibuprofen (IBU), and phenylephrine hydrochloride (PHE) were $4.2 \mathrm{~min}, 13.6 \mathrm{~min}$, and $2.7 \mathrm{~min}$, respectively. The proposed method was validated with respect to linearity, accuracy, precision, specificity, and robustness. The linearity for chlorpheniramine maleate, ibuprofen, and phenylephrine hydrochloride was in the range of $0.5-2.5 \mu \mathrm{g} / \mathrm{mL}, 25-125 \mu \mathrm{g} / \mathrm{mL}$, and $1.25-6.25 \mu \mathrm{g} / \mathrm{mL}$, respectively. The \% recoveries of all the three drugs were found to be $99.44-101.61 \%, 99.39-101.79 \%$, and $98.66-101.83 \%$. LOD were found to be 32,120 , and $68 \mathrm{ng} / \mathrm{mL}$ for CPM, IBU, and PHE, respectively. The method was successfully applied to the estimation of chlorpheniramine maleate, ibuprofen, and phenylephrine hydrochloride in combined pharmaceutical dosage form.
\end{abstract}

\section{Introduction}

3-(4-chlorophenyl)-N,N-dimethyl-3-pyridin-2-ylpropan-1amine is the IUPAC name of the chlorpheniramine maleate (CPM). The empirical formula for CPM is $\mathrm{C}_{20} \mathrm{H}_{23} \mathrm{ClN}_{2} \mathrm{O}_{4}$ (Figure 1: chemical structure of CPM salt). CPM is a $\mathrm{H}-1$ receptor blocker. CPM is an antihistamine used to relieve symptoms of allergy, hay fever, and the common cold. These symptoms include rash, watery eyes, itchy eyes/nose/ throat/skin, cough, runny nose, and sneezing. 2-[4-(2-methyl-propyl)phenyl]propanoic acid is the IUPAC name of the ibuprofen (IBU). The empirical formula for IBU is $\mathrm{C}_{13} \mathrm{H}_{18} \mathrm{O}_{2}$ (Figure 2: chemical structure of IBU). IBU is a nonselective inhibitor of COX-2, an enzyme involved in prostaglandin synthesis of the arachidonic acid pathway. Its pharmacological effects are believed to be due to inhibition of COX-2 which decrease the synthesis of prostaglandin involved in mediating inflammation pain, fever, and swelling. (R)-1-(3-hydroxyphenyl)-2-methylamino-ethanol hydrochloride is the IUPAC name of phenylephrine hydrochloride (PHE). The empirical formula for PHE is $\mathrm{C}_{9} \mathrm{H}_{13} \mathrm{NO}_{2} \mathrm{HCl}$ (Figure 3: chemical structure of PHE). PHE is $\alpha$-adrenoreceptor agonist, decreases nasal congestion, and increases drainage of sinus cavities. The combination dosage form of CPM, IBU, and PHE is available in the market and it is indicated in the treatment of allergy, congestion relief, and fever reducer [1-5].

These drugs are official in Indian Pharmacopoeia, British Pharmacopoeia, and United states Pharmacopoeia [3-5].

A literature survey regarding quantitative analysis of these drugs revealed that attempts have been made to develop analytical methods for the estimation of chlorpheniramine maleate alone and in combination with other drugs by liquid chromatographic (HPLC) [6-10] and HPTLC [11, 12]. The 
<smiles>CN(CCC(c1ccc(Cl)cc1)c1ccccn1)C[Hg]OC(=O)/C=C\C(=O)O</smiles>

FIGURE 1: Structure of chlorpheniramine maleate.<smiles>CC(C)Cc1ccc(C(C)C(=O)O)cc1</smiles>

FIGURE 2: Structure of ibuprofen.

liquid chromatographic (HPLC) [13], HPTLC [14, 15], and spectrophotometric methods $[16,17]$ have been reported for the estimation of ibuprofen alone and in combination with other drugs. The spectrophotometric method [18], liquid chromatography (HPLC) $[6,9]$, and HPTLC $[11,12,19,20]$ methods have been reported for the estimation of phenylephrine hydrochloride alone and in combination with other drugs.

There is no method reported for the simultaneous estimation of CPM, IBU, and PHE in combined dosage form. The present study involved the development and validation of RPHPLC method for the estimation of CPM, IBU, and PHE in combined pharmaceutical dosage form.

\section{Experimental}

2.1. Reagents and Materials. Analytically pure CPM, IBU, and PHE were obtained as gift samples from Elite Pharma Pvt. Ltd., Ahmedabad, India. HPLC grade methanol and acetonitrile were obtained from SRL Ltd., Mumbai, India. The water was distilled and deionised by using Millipore (Vienna, Austria) Milli Q Ultrapure system. Tablet formulation (ADVIL allergy and congestion relief, Pfizer Pharmaceutical, Madison, USA) containing labeled amount of $4 \mathrm{mg}$ of chlorpheniramine maleate, $200 \mathrm{mg}$ of ibuprofen, and $10 \mathrm{mg}$ of phenylephrine hydrochloride was used for the study.

2.2. Apparatus. The liquid chromatographic system consists of Waters series 2998 (Shelton, USA) equipped with a series PDA detector, series 515 quaternary pump, and manual injector rheodyne valve with $20 \mu \mathrm{L}$ fixed loop. The analytes were monitored at $220 \mathrm{~nm}$. Chromatographic analysis was performed on Sunfire C 18 column $(5 \mu \mathrm{m} \times 250 \mathrm{~mm} \times 4.6 \mathrm{~mm})$. All the drugs and chemicals were weighed on Shimadzu electronic balance (AX 200, Shimadzu Corp., Japan).

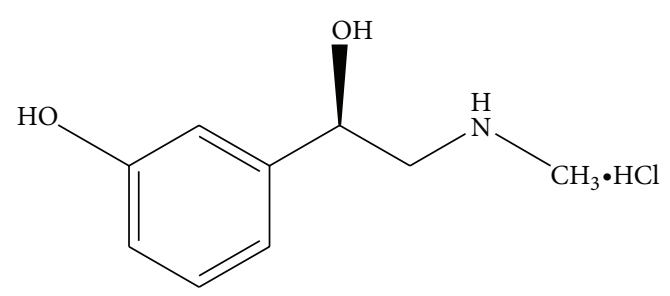

FIGURE 3: Structure of phenylephrine hydrochloride.

2.3. Chromatographic Conditions. The Sunfire C 18 column $(5 \mu \mathrm{m} \times 250 \mathrm{~mm} \times 4.6 \mathrm{~mm})$ equilibrated with mobile phase acetonitrile: methanol: phosphate buffer $(50: 20: 30, \mathrm{v} / \mathrm{v} / \mathrm{v}$; $\mathrm{pH}$ 5.6) and adjusted with $0.01 \% \mathrm{O}$-phosphoric acid was used. The flow rate was maintained at $1 \mathrm{~mL} / \mathrm{min}$, eluents were monitored with UV detector at $220 \mathrm{~nm}$, and the injection volume was $20 \mu \mathrm{L}$. Total run time was kept for $15 \mathrm{~min}$.

2.4. Preparation of Standard Stock Solutions. CPM, IBU, and PHE were weighed (10 mg each) and transferred to three separate $10 \mathrm{~mL}$ volumetric flasks and volumes were made up to the mark with mobile phase to yield a solution containing $1000 \mu \mathrm{g} / \mathrm{mL}$ of CPM, IBU, and PHE, respectively. Appropriately diluted with mobile phase to obtain working standard of CPM $100 \mu \mathrm{g} / \mathrm{mL}$, IBU $1000 \mu \mathrm{g} / \mathrm{mL}$ and PHE $100 \mu \mathrm{g} / \mathrm{mL}$ were used as a working standard.

2.5. Method Validation. The proposed method was subjected to validation for various parameters like linearity and range, precision, accuracy, and robustness in accordance with International Conference on Harmonization Guidelines.

2.5.1. Linearity. Appropriate aliquots of CPM, IBU, and PHE working standard solutions were taken in different $10 \mathrm{~mL}$ volumetric flasks and diluted up to the mark with mobile phase to obtain final concentrations of $0.5,1.0,1.5,2.0$, and $2.5 \mu \mathrm{g} / \mathrm{mL}$ of CPM, 25, 50, 75, 100 , and $125 \mu \mathrm{g} / \mathrm{mL}$ of IBU, and $1.25,2.50,3.75,5.00$, and $6.25 \mu \mathrm{g} / \mathrm{mL}$ of PHE, respectively. The solutions were injected using a $20 \mu \mathrm{L}$ fixed loop system and chromatograms were recorded. Calibration curves were constructed by plotting average peak area versus concentrations and regression equations were computed for all three drugs.

2.5.2. Precision. The repeatability studies were carried out by estimating response of CPM $(2 \mu \mathrm{g} / \mathrm{mL})$, IBU $(100 \mu \mathrm{g} / \mathrm{mL})$, and PHE $(5 \mu \mathrm{g} / \mathrm{mL})$ six times and results were reported in terms of relative standard deviation. The intraday and interday precision studies (intermediate precision) were carried out by estimating the corresponding responses 3 times on the same day and on 3 different days for three different concentrations of CPM $(0.5,1.5$, and $2.5 \mu \mathrm{g} / \mathrm{mL}), \operatorname{IBU}(25,75$, and $125 \mu \mathrm{g} / \mathrm{mL})$, and PHE $(1.25,3.75$, and $6.25 \mu \mathrm{g} / \mathrm{mL})$, and the results were reported in terms of relative standard deviation.

2.5.3. Accuracy. The accuracy of the method was determined by calculating recoveries of CPM, IBU, and PHE by method 
of standard additions. Known amounts of CPM $(0,0.5,1.0$, and $1.5 \mu \mathrm{g} / \mathrm{mL})$, IBU $(0,25,50$, and $75 \mu \mathrm{g} / \mathrm{mL})$, and PHE $(0$, $1.25,2.50$, and $3.75 \mu \mathrm{g} / \mathrm{mL}$ ) were added to a prequantified sample solution, and the amounts of CPM, IBU, and PHE were estimated by measuring the peak areas and by fitting these values to the straight-line equation of calibration curve.

2.5.4. Detection Limit and Quantitation Limit. The LOD and LOQ were calculated using the following equation as per ICH guidelines:

$$
\mathrm{LOD}=3.3 \times \frac{\sigma}{S}, \quad \mathrm{LOQ}=10 \times \frac{\sigma}{S},
$$

where $\sigma$ is the standard deviation of $y$-intercepts of regression lines and $S$ is the slope of the calibration curve.

2.5.5. Robustness. Robustness of the method was studied by deliberately changing the experimental conditions like flow rate and percentage of mobile phase ratio. The study was carried out by changing $5 \%$ of the mobile phase ratio and $0.1 \mathrm{~mL} / \mathrm{min}$ of flow rate.

2.5.6. Solution Stability. The solutions were prepared and solution stability was checked for 3, 9, 12, and 24 hrs by checking the area over the period of time, using the different analysts and the same instrument.

2.5.7. System Suitability. A system suitability test was an integral part of the method development to verify that the system is adequate for the analysis of CPM, IBU, and PHE to be performed. System suitability test of the chromatography system was performed before each validation run. Five replicate injections of a system suitability standard and one injection of a check standard were made. Area, retention time (RT), tailing factor, asymmetry factor, and theoretical plates for the five suitability injections were determined.

2.6. Analysis of Marketed Formulation. Twenty tablets were accurately weighed and finely powdered. Tablet powder equivalent to $4 \mathrm{mg}$ CPM, $200 \mathrm{mg}$ of IBU, and $10 \mathrm{mg}$ of PHE was taken in $100 \mathrm{~mL}$ volumetric flask. Methanol $(50 \mathrm{~mL})$ was added to the above flask and the flask was sonicated for 15 minutes. The solution was filtered using Whatman filter paper No. 41 and volume was made up to the mark with the mobile phase.

Appropriate volume of the aliquot was transferred to a $10 \mathrm{~mL}$ volumetric flask and the volume was made up to the mark with the mobile phase to obtain a solution containing $1.0 \mu \mathrm{g} / \mathrm{mL}$ of CPM, $50 \mu \mathrm{g} / \mathrm{mL}$ of IBU, and $2.50 \mu \mathrm{g} / \mathrm{mL}$ of PHE. The solution was sonicated for $10 \mathrm{~min}$. It was injected as per the above chromatographic conditions and peak areas were recorded. The quantifications were carried out by keeping these values to the straight line equation of calibration curve.

\section{Results and Discussion}

3.1. Optimization of Mobile Phase. The optimization of mobile phase was to resolve chromatographic peaks for active drug ingredients with less asymmetric factor.

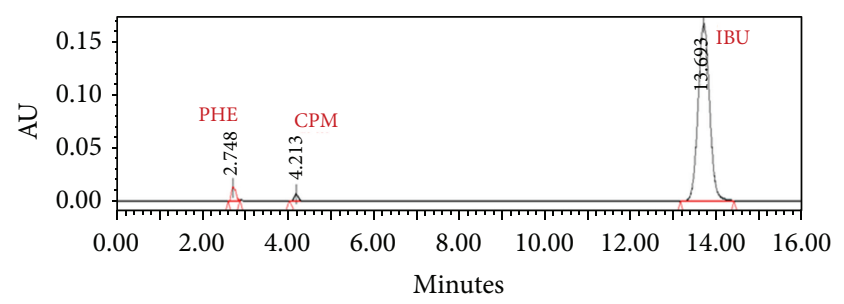

FIgURE 4: Chromatogram of CPM, IBU, and PHE.

There were many mobile phases that tried to resolve all three chromatographic peaks, in that first with simple methanol: water $(70: 30, \mathrm{v} / \mathrm{v})$, methanol: water $(50: 50, \mathrm{v} / \mathrm{v})$, methanol: water $(40: 60, \mathrm{v} / \mathrm{v})$, but we found broadness of peaks and could not get satisfactory results in these chromatograms. To improve these, we worked with phosphate buffer and for sharpness of chromatographic peaks we worked with acetonitrile with slightly acidic condition. So, acetonitrile:phosphate buffer $(70: 30, \mathrm{v} / \mathrm{v})(\mathrm{pH}: 5.6)$ was adjusted with $0.01 \% \mathrm{O}$-phosphoric acid peaks which were resolved but merged CPM and PHE peak and PHE peak with void volume at $1.9 \mathrm{~min}$. So acetonitrile: phosphate buffer $(60: 40)(\mathrm{pH}: 5.6, \mathrm{v} / \mathrm{v})$ was adjusted with $0.01 \% \mathrm{O}$-phosphoric acid but PHE peak with void volume. So we added methanol and peak of PHE in Acetonitrile:methanol:phoshphate buffer mobile phase got at above $2.5 \mathrm{~min}$; therefore, acetonitrile : methanol : phosphate buffer $(50: 10: 40, \mathrm{v} / \mathrm{v} / \mathrm{v})(\mathrm{pH}: 5.6)$ was adjusted with $\mathrm{O}$-phosphoric acid PHE peak at $2.5 \mathrm{~min}$, CPM peak at $3.8 \mathrm{~min}$, and IBU peak at $24 \mathrm{~min}$. We add more $10 \%$ of methanol and, IBU peak at $13.6 \mathrm{~min}$.

Finally, the mobile phase acetonitrile:methanol:phosphate buffer $(50: 20: 30, \mathrm{v} / \mathrm{v} / \mathrm{v})(\mathrm{pH}: 5.6)$ adjusted with $0.01 \%$ $\mathrm{O}$-phosphoric acid was found to be satisfactory which gave three symmetric and well-resolved peaks for CPM, IBU, and PHE. The retention times for CPM, IBU, and PHE were $4.2 \mathrm{~min}, 13.6 \mathrm{~min}$, and $2.7 \mathrm{~min}$, respectively (Figure 4). The resolutions between PHE \& CPM, PHE \& IBU, and CPM \& IBU were found to be $4.5,16.8$, and 15.2 , respectively, which indicates good separation of all compounds. The mobile phase flow rate was maintained at $1 \mathrm{~mL} / \mathrm{min}$. Overlain UV spectra of the drugs showed that CPM, IBU, and PHE absorbed appreciably at $220 \mathrm{~nm}$, so detection was carried out at $220 \mathrm{~nm}$ (Figure 5).

3.2. Method Validation. The calibration curve for CPM was found to be linear in the range of $0.5-2.5 \mu \mathrm{g} / \mathrm{mL}$ with a correlation coefficient of 0.998 . The calibration curve for IBU was found to be linear in the range of $25-125 \mu \mathrm{g} / \mathrm{mL}$ with a correlation coefficient of 0.996 . The calibration curve for PHE was found to be linear in the range of $1.25-6.25 \mu \mathrm{g} / \mathrm{mL}$ with a correlation coefficient of 0.997 . Instrument precision was determined by performing injection repeatability test and the RSD values for CPM, IBU, and PHE were found to be $1.38 \%$, $0.57 \%$, and $0.44 \%$, respectively. The intraday and interday precision studies were carried out and the results are reported in Table 1 . The low RSD values indicate that the method is precise. 
TABLE 1: Validation parameters for CPM, IBU, and PHE.

\begin{tabular}{lccc}
\hline Parameters & CPM & IBU & PHE \\
\hline Linearity (range) $(\mu \mathrm{g} / \mathrm{mL})$ & $0.5-2.5$ & $25-125$ & $1.25-6.25$ \\
Retention time $(\mathrm{min})$ & 4.2 & 13.6 & 2.7 \\
Detection limit $(\mu \mathrm{g} / \mathrm{mL})$ & 0.0321 & 0.1198 & 0.0679 \\
Quantitation limit $(\mu \mathrm{g} / \mathrm{mL})$ & 0.5 & 25 & 1.25 \\
Accuracy $(\%)$ & $99.44-101.61$ & $99.39-101.79$ & $99.66-101.83$ \\
Precision (RSD\%) & & & $0.10-0.23$ \\
$\quad$ Intraday precision $(n=3)$ & $0.44-1.28$ & $0.66-1.33$ & $0.38-0.56$ \\
$\quad$ Interday precision $(n=3)$ & $0.98-1.46$ & 0.57 & $0.66-1.53$ \\
Instrument precision $(\mathrm{RSD} \%)^{\mathrm{a}}(n=6)$ & 1.38 & 0.12 \\
\hline
\end{tabular}

${ }^{a} \mathrm{RSD}$ is relative standard deviation and " $n$ " is number of determinations.

TABLE 2: Robustness study of CPM, IBU, and PHE.

\begin{tabular}{|c|c|c|c|c|}
\hline \multirow{2}{*}{ Method parameter/condition } & \multirow{2}{*}{ Deliberate changes } & \multicolumn{3}{|c|}{$\%$ RSD of peak area $(n=3)$} \\
\hline & & $\mathrm{CPM}$ & IBU & PHE \\
\hline \multirow{2}{*}{ Flow rate } & $0.9 \mathrm{~mL} / \mathrm{min}$ & 0.89 & 1.26 & 1.63 \\
\hline & $1.1 \mathrm{~mL} / \mathrm{min}$ & 1.23 & 1.39 & 1.73 \\
\hline Mobile phase ratio & $45: 25: 30$ & 1.24 & 1.38 & 1.82 \\
\hline Acetonitrile : methanol : phosphate buffer & $55: 15: 30$ & 1.28 & 1.73 & 1.17 \\
\hline
\end{tabular}

TABLE 3: System suitability parameters.

\begin{tabular}{lccc}
\hline Parameter & CPM & IBU & PHE \\
\hline Retention time $(\mathrm{min})$ & 4.2 & 13.6 & 2.7 \\
Theoretical plates & 4155.36 & 4324.06 & 3986.31 \\
Tailing factor & 0.67 & 1.03 & 1.25 \\
\hline
\end{tabular}

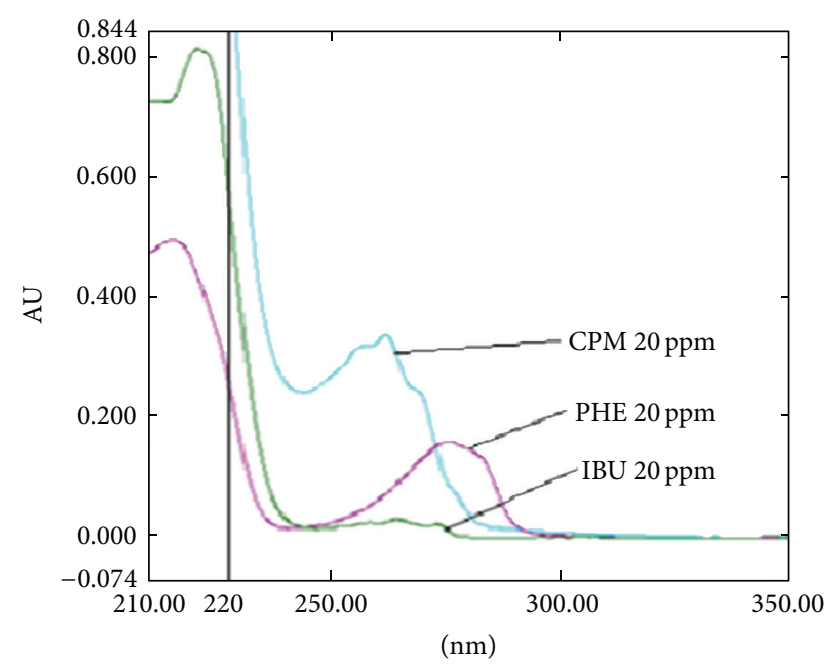

Figure 5: Overlain UV spectra of CPM, IBU, and PHE (20 ppm).

The accuracy of the method was determined by calculating recoveries of CPM, IBU, and PHE by method of standard addition. The recoveries were found to be $99.44-101.61 \%$, 99.39-101.79\%, and 98.66-101.83\% for CPM, IBU, and PHE, respectively. The results are reported in Table 1 . The high values indicate that the method is accurate.

The detection limits for CPM, IBU, and PHE were found to be $32 \mathrm{ng} / \mathrm{mL}, 120 \mathrm{ng} / \mathrm{mL}$, and $68 \mathrm{ng} / \mathrm{mL}$, respectively, while quantitation limits were found to be $0.1 \mu \mathrm{g} / \mathrm{mL}, 0.4 \mu \mathrm{g} / \mathrm{mL}$, and $0.2 \mu \mathrm{g} / \mathrm{mL}$, respectively. The above data shows that a nanogram quantity of the drugs can be accurately and precisely determined. Robustness study was performed by deliberately changing the experimental conditions like flow rate from $1 \mathrm{~mL} / \mathrm{min}$ to $0.8 \mathrm{~mL} / \mathrm{min}$ and $1.2 \mathrm{~mL} / \mathrm{min}$. The composition of mobile phase was changed varying the proportion of acetonitrile by $5 \%$. In both conditions the recoveries of both drugs were determined and the RSD was found to be less than $2 \%$. The results are reported in Table 2 .

System suitability parameters such as the number of theoretical plates, resolution, and tailing factor were determined. System suitability test was carried out and the results are summarized in Table 3. Asymmetric factors for CPM, IBU, and PHE are 1.0, 1.11, and 0.944, respectively.

Stability of standard and sample solution of CPM, IBU, and PHE were evaluated at room temperature. The solutions of the three drugs were found to be stable for $0,3,6$, and 24 hrs. The results are reported in Table 4 . All three drugs were found to be stable with a recovery of more than $98 \%$.

3.3. Analysis of Marketed Formulations. The proposed method was successfully applied to the determination of CPM, IBU, and PHE in their combined dosage form. The \% recovery \pm S.D. was found to be $100.37 \pm 1.24,100.24 \pm 1.55$, and $100.91 \pm 1.25$, respectively, for CPM, IBU, and PHE (Table 5) which were comparable with the corresponding labeled amounts.

\section{Conclusion}

The concentration of CPM, IBU, and PHE in pharmaceutical dosage form could be satisfactorily determined using isocratic RP-HPLC system with PDA detector.

This study had shown that PDA detector was sensitive, accurate, and simple method for the determination of the 
TABLE 4: Solvent stability study.

\begin{tabular}{|c|c|c|c|c|c|c|}
\hline \multirow[b]{2}{*}{$\begin{array}{l}\text { Time } \\
\text { (Hrs.) }\end{array}$} & \multicolumn{3}{|c|}{ Area $(n=3)$} & \multicolumn{3}{|c|}{ Result \% } \\
\hline & $\begin{array}{c}\text { CPM } \\
2(\mu \mathrm{g} / \mathrm{mL}) \\
\end{array}$ & $\begin{array}{c}\text { IBU } \\
100(\mu \mathrm{g} / \mathrm{mL})\end{array}$ & $\begin{array}{c}\text { PHE } \\
5(\mu \mathrm{g} / \mathrm{mL}) \\
\end{array}$ & $\mathrm{CPM}$ & IBU & PHE \\
\hline 0 & 61521 & 4158429 & 124685 & 100 & 100 & 100 \\
\hline 3 & 61009 & 4146734 & 123619 & 99.16 & 99.14 & 99.14 \\
\hline 6 & 60913 & 4116520 & 121706 & 99.01 & 98.99 & 97.61 \\
\hline 24 & 60157 & 4104629 & 120648 & 98.71 & 98.70 & 96.76 \\
\hline
\end{tabular}

TABLE 5: Analysis of marketed preparation.

\begin{tabular}{|c|c|c|c|c|c|c|}
\hline \multirow{2}{*}{ Formulation } & \multicolumn{3}{|c|}{ Labelled amount (mg) } & \multicolumn{3}{|c|}{ \% Recovery ${ }^{\mathrm{b}}$} \\
\hline & $\mathrm{CPM}$ & IBU & PHE & $\mathrm{CPM}$ & IBU & PHE \\
\hline ADVIL allergy and congestive relief & 4 & 200 & 10 & $100.37 \pm 1.24$ & $100.23 \pm 1.55$ & $100.91 \pm 1.25$ \\
\hline
\end{tabular}

active ingredients in ADVIL allergy and congestion relief tablet.

This method has been found suitable for the routine analysis of pharmaceutical dosage forms in QC and R \& D Laboratories for product of similar type and composition.

\section{Disclosure}

The authors have no conflict of interests or no financial gains in mentioning the company names or trademarks. The usage of this trademark symbol or company name is for proving the genuinity of the work and not for any other purpose. As the authors of the paper, they do not have any financial relation with the commercial identity in the paper.

\section{Acknowledgments}

The authors are thankful to Elite Pharma Pvt. Ltd., Ahmedabad, India, for providing gift sample of CPM, IBU, and PHE. The authors are very thankful to Principal, Indukaka Ipcowala College of Pharmacy, New Vallabh Vidyanagar for providing necessary facilities to carry out research work.

\section{References}

[1] M. d. J. O'niel and P. E. Hackelman, Merk Index-An Encyclopaedia of Chemicals, Drugs and Biological, Merk Research laboratory,, 13th edition, 2006.

[2] K. D. Tripathi, Essentials of Medicinal Pharmacology, Jaypee Brothers Medical Publisher LTD, New Delhi, India, 5th edition, 2003.

[3] British Pharmacoeia, The Stationary Office on Behalf of the Medicine and Healthcare Products Regulatory Agency (MHRA), vol. 3, London, UK, 2007.

[4] Indian Pharmacopoeia, "Indian pharmacopoeial commission," Ghaziabad, India, 5th edition 2010, vol 2, pp 1071-72, 1479-83, v 3, pp. 1900.

[5] United States Pharmacopoeia and National Formulary, (22th) Asian Edition, The United States Pharmacopoeia Convention Inc., U.S.A., pp. 427-30, 953-55, 1471-73.
[6] M. Maithani, R. Raturi, G. Vertika, and D. Kumar, "Development \& validation of RP-HPLC method for the determination of chlorpheniramine maleate and phenylephrine $\mathrm{HCl}$ in pharmaceutical dosage form," International Research Journal of Pharmacy, vol. 5, pp. 1-4, 2010.

[7] L. E. Geetha and S. M. Rama, "A novel RP-HPLC method for simultaneous estimation of codeine phosphate, chlorpheniramine maleate and its preservative in syrup formulation," International Journal of Pharmacy and Pharmaceutical Sciences, vol. 4, supplement 3, pp. 585-590, 2012.

[8] D. B. Wanjari, V. V. Parashar, S. N. Lulay, M. R. Tajne, and N. J. Gaikwad, "Simultaneous HPLC estimation of acetaminophen, chlopheniramine maleate, dextromethorphan hydrobromide and pseudoephedrine hydrochloride in tablets," Indian Journal of Pharmaceutical Sciences, vol. 66, no. 3, pp. 345-347, 2004.

[9] H. Senyuva and T. Özden, "Simultaneous high-performance liquid chromatographic determination of paracetamol, phenylephrine $\mathrm{HCl}$, and chlorpheniramine maleate in pharmaceutical dosage forms," Journal of Chromatographic Science, vol. 40, no. 2, pp. 97-100, 2002.

[10] S. Rajurkar, "Simultaneous determination of chlorpheniramine maleate, paracetamol, pseudoephedrine $\mathrm{HCl}$ in pharmaceutical dosage form by HPLC method," International Journal of Life Science and Pharma Research, vol. 1, no. 1, pp. 94-100, 2011.

[11] S. Subramanyan and S. G. Das, "HPTLC method forsimultaneous estimation of chlorpheniramine maleate, phenylephrine in pharmaceutical dosage form," Journal of AOAC International. In press.

[12] N. Hunan and S. Multal, "Densitometric analysis of chlorpheniramine maleate, phenylephrine and acetaminophen by HPTLC method," Analytical LetterIssue, vol. 19, no. 7-8, 1986.

[13] P. B. Reddy and M. S. Reddy, "RP-HPLC method for simultaneous estimation of paracetamol and ibuprofen in tablets," Asian Journal of Research in Chemistry, vol. 2, no. 1, pp. 70-72, 2009.

[14] S. Chitlange, D. Sakarkar, S. Wankhede, and S. Wadodkar, "High performance thin layer chromatographic method for simultaneous estimation of ibuprofen and pseudoephedrine hydrochloride," Indian Journal of Pharmaceutical Sciences, vol. 70, no. 3, pp. 398-400, 2008.

[15] R. V. Rele and S. A. Sawant, "Determination of paracetamol and ibuprofen from combined dosage formulation by HPTLC method," Analytical Chemistry, vol. 9, no. 1, pp. 302-305, 2010. 
[16] R. Gondalia, R. Mashru, and P. Savaliya, "Development and validation of spectrophotometric methods for simultaneous estimation of IBUPROFEN and PARACETAMOL in soft gelatin capsule by simultaneous equation method," International Journal of ChemTech Research, vol. 2, no. 4, pp. 1881-1885, 2010.

[17] I. M. Palabiyik, E. Dinç, and F. Onur, "Simultaneous spectrophotometric determination of pseudoephedrine hydrochloride and ibuprofen in a pharmaceutical preparation using ratio spectra derivative spectrophotometry and multivariate calibration techniques," Journal of Pharmaceutical and Biomedical Analysis, vol. 34, no. 3, pp. 473-483, 2004.

[18] L. K. Soni, T. Narsinghani, and C. Saxena, "Development and validation of UV-Spectrophotometric assay protocol for simultaneous estimation of ebastine and phenylephrine hydrochloride in tablet dosage form using simultaneous equation method," International Journal of ChemTech Research, vol. 3, no. 4, pp. 1918-1925, 2011.

[19] P. V. Devarajan, M. H. Adani, and A. S. Gandhi, "Simultaneous determination of lignocaine hydrochloride and phenylephrine hydrochloride by HPTLC," Journal of Pharmaceutical and Biomedical Analysis, vol. 22, no. 4, pp. 685-690, 2000.

[20] I. Wouters, E. Roets, and J. Hoogmartens, "Analysis of tablets containing acetylsalicylic acid and phenylephrine by high-performance liquid chromatography," Journal of Pharmaceutical and Biomedical Analysis, vol. 2, no. 3-4, pp. 481-490, 1984. 

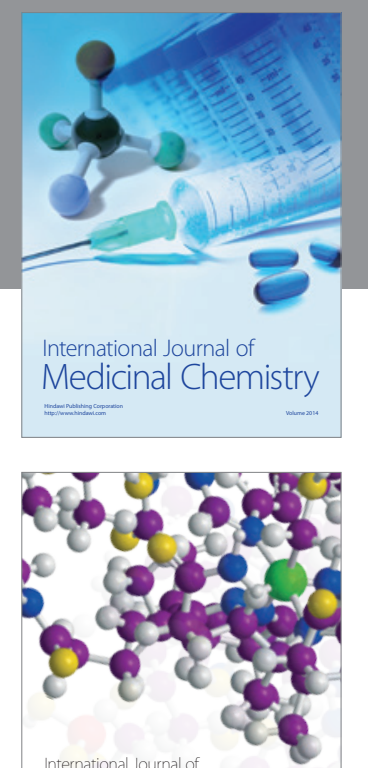

\section{Carbohydrate} Chemistry

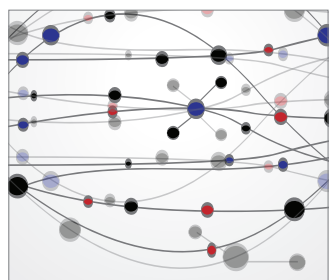

The Scientific World Journal
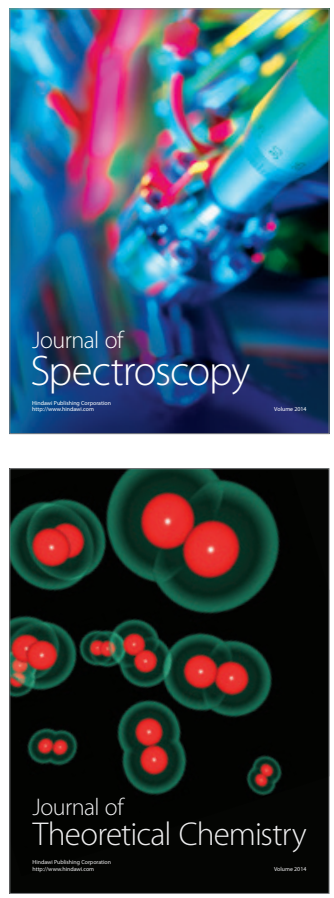
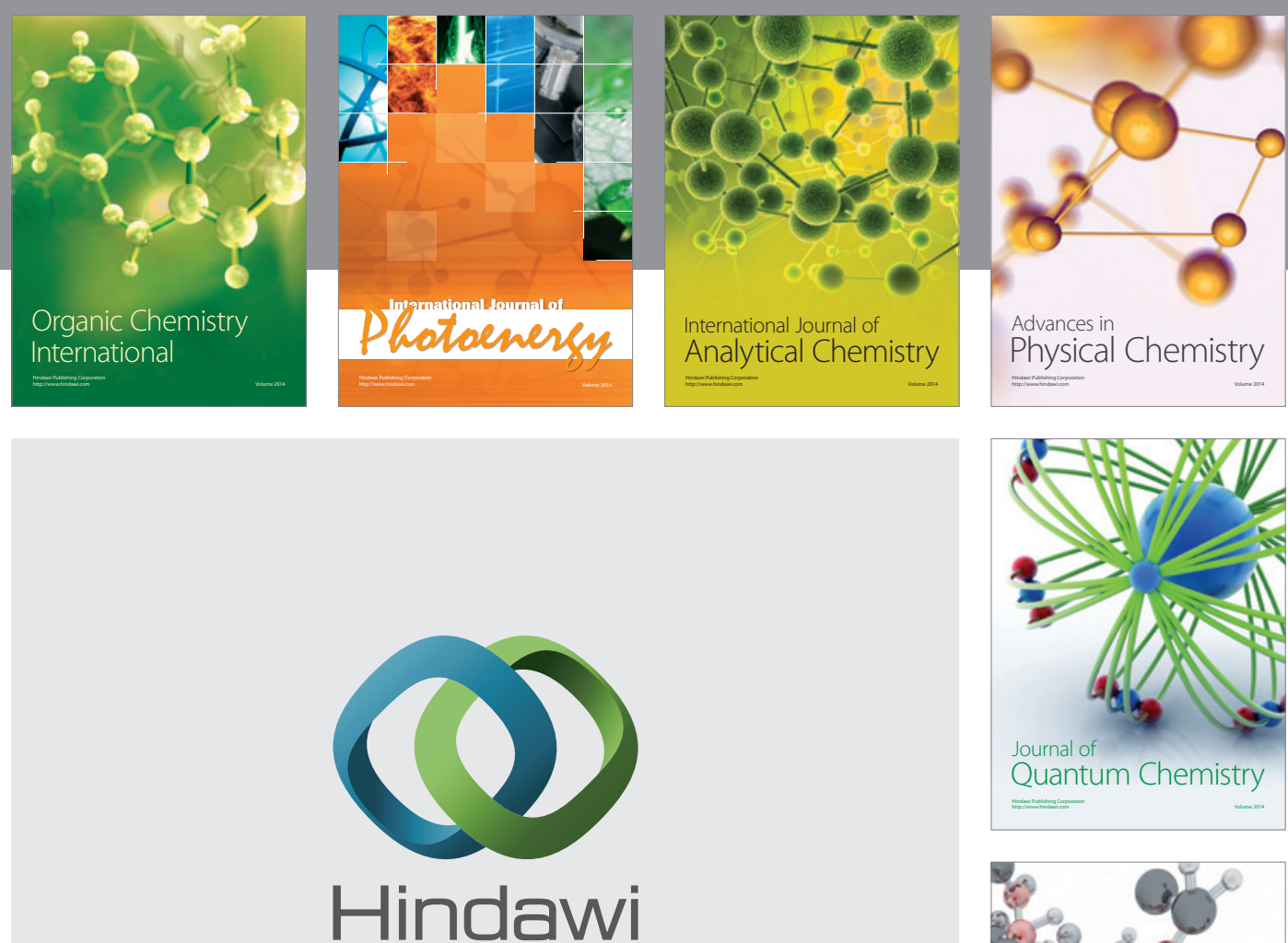

Submit your manuscripts at

http://www.hindawi.com

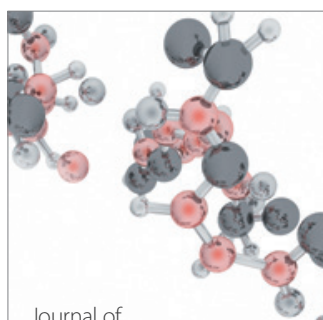

Analytical Methods

in Chemistry

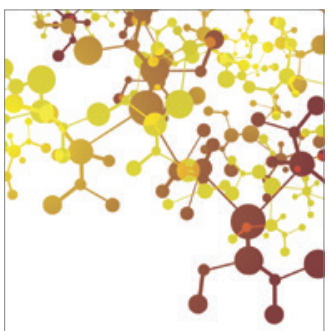

Journal of

Applied Chemistry

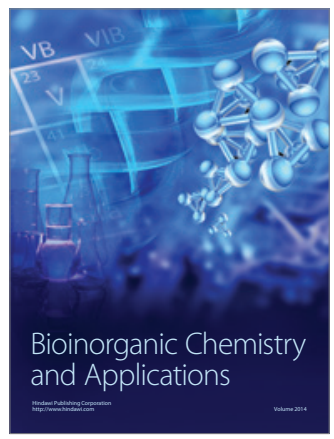

Inorganic Chemistry
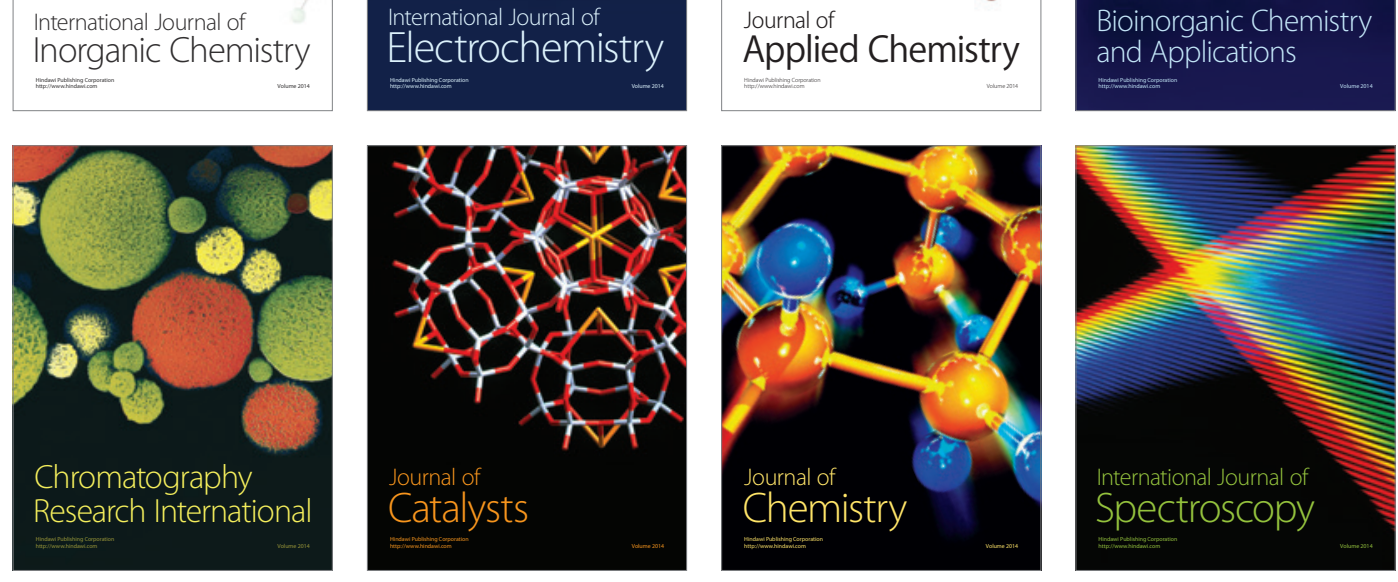